\title{
The Exigencies of Surgery in Orthopaedics Today
}

\author{
Rakesh Bhargava* \\ Department of orthopaedics, National institute of Medical sciences and Research, India
}

Submission: March 01, 2018; Published: March 19, 2018

*Corresponding author: Rakesh Bhargava, Professor and head, Dept of orthopaedics, National institute of Medical Sciences and Research, Jaipur, India, Email: drrakeshbhargava@hotmail.com

\section{Opinion}

Every surgery has indications, which may be absolute or relative. This is what I studied and was taught by my peer, Dr P K Sethi, known more for his association with the Jaipur Foot. However, over the years I have seen a sea change in the exigencies of surgery. The reasons are myriad when I was doing my postgraduation, in the late 1970s; there were very few implants manufactures in India. Implant surgery was not so frequent, or popular. As the industry grew, the need for implants also grew. Of consequence here is that what should have been the other way around, the effect was preceding the cause. Surgeons were not operating more as the indications were growing, but the increasing competition in the implant industry was firing a new form of impetus, namely commissions on the implants.

Somewhere down the line, The AO organisation came out with its manuals and philosophy of virtual universal fixation of fractures, from every long bone to every short bone, from femurs and pelvis to clavicle and ribs. There is much to say about the pros and cons of this philosophy, much has been written on the long term and the short-term benefits of these fixations, the complications and drawbacks of not leaving some of these fractures and injuries well alone. The beauty of scientific data is that it can deduce whatever is demanded of it or needed from it. All that is needed is the use of certain adjectives like 'short term or immediate gain's or certain phrases like 'for cosmetic appearances' or 'early functional outcome'.

The significant result of this rapid growth of the implant industry both domestic, and foreign manufacturers entering

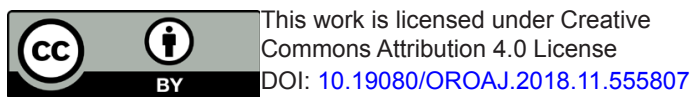

Indian markets and establishing themselves here, was that everything shot out of proportions, the number of surgeries, the volume of patients subjected to surgeries, the implants consumption, and with all this, the tremendous influx in the monetary gains of commissions and payouts to the surgeons. This opened a vicious cycle where the industry was pushing for use of its products; the surgeons were succumbing to this coercion as this was resulting in increased financial gains, which in turn prompted more surgeries and use of more implants.

What was lost in all this rigmarole of modern day contemporary treatment modality was the old-fashioned indications and contra indication of surgery and the now virtually derelict concept of conservative management of fractures? Brushing aside all indications for any surgery, the paramount indication has become "If I don't do it, someone else will". Confounding this mindset is the game of numbers, who does the first, the hundredth, the thousandth and so on and so forth. Adding insult to the injury are the advertisements that are so grotesque and magnified, sometimes so overly simplified to interest and impress the less educated or inclined. These practices have eclipsed the reasoning and consultations of the senior practitioners who have been relegated to the heap of 'old hats' who have either 'lost it' or lost their relevance in a precipitously transforming orthopedic scenario. Orthopedist like me are just floating and flowing in the quagmire that is now this rat race. In the words of that Urdu poet Sahir Ludhianvi, "Aur hum khadhe khadhe, neer nain main bhare, umr ke chadhav ka utar dekhte rahe, Karwan gujar gaya, gubar dekhte rahe."

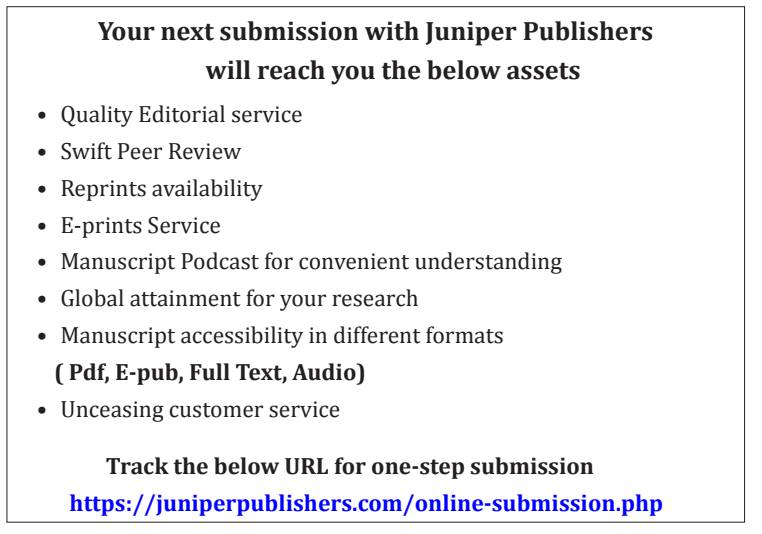

